\title{
Correction to: A new diagnostic real-time PCR method for huanglongbing detection in citrus root tissue
}

\author{
Jong-Won Park ${ }^{1}$ (D) Eliezer S. Louzada ${ }^{1}$. W. Evan Braswell ${ }^{2}$ Philip A. Stansly ${ }^{3}$ John V. da Graça ${ }^{1} \cdot$ Greg McCollum $^{4}$. \\ John E. Rascoe ${ }^{5} \cdot$ Madhurababu Kunta $^{1}$
}

Published online: 14 August 2018

(c) The Author(s) 2018

\section{Correction to: Journal of General Plant Pathology https://doi.org/10.1007/s10327-018-0793-4}

The article "A new diagnostic real-time PCR method for huanglongbing detection in citrus root tissue", written by Jong Won Park, Eliezer S. Louzada, W. Evan Braswell, Philip A. Stansly, John V. da Graça, Greg McCollum, John E. Rascoe, and Madhurababu Kunta, was originally published electronically on the publisher's internet portal (currently SpringerLink) on 13 June 2018 without open access.

With the author(s)' decision to opt for Open Choice the copyright of the article changed on 3 August 2018 to (c) The Author(s) 2018 and the article is forthwith distributed under the terms of the Creative Commons Attribution 4.0 International License (http://creativecommons.org/licenses/ by/4.0/), which permits use, duplication, adaptation, distribution and reproduction in any medium or format, as long as you give appropriate credit to the original author(s) and the source, provide a link to the Creative Commons license and indicate if changes were made.

The original article has been corrected.

Open Access This article is distributed under the terms of the Creative Commons Attribution 4.0 International License (http://creativeco mmons.org/licenses/by/4.0/), which permits unrestricted use, distribution, and reproduction in any medium, provided you give appropriate credit to the original author(s) and the source, provide a link to the Creative Commons license, and indicate if changes were made.
The original article can be found online at https://doi.org/10.1007/ s10327-018-0793-4.

\section{Madhurababu Kunta}

madhura.kunta@tamuk.edu

1 Texas A \& M University-Kingsville Citrus Center, 312 N. International Blvd, Weslaco, TX 78599, USA

2 Mission Laboratory, USDA APHIS PPQ CPHST, Edinburg, TX 78539, USA

3 Southwest Florida Research and Education Center, University of Florida-IFAS, Immokalee, FL 334142, USA

4 USDA-ARS Horticultural Research Laboratory, Fort Pierce, FL 34945, USA

5 Beltsville Laboratory, USDA APHIS PPQ CPHST, Beltsville, MD 20705, USA 